\title{
Tax Compliance Behavior of Taxpayer: Challenge in achieving tax target
}

\author{
Siti Ngatikoh \\ Graduate student of Department of Public Policy and Management, \\ Faculty of Social and Political Sciences, Universitas Gadjah Mada \\ aisya_tuzzahra@yahoo.com
}

\begin{abstract}
This study review about research tax compliance behavior to challenge in achieving tax target. According behavioral approach that any behavior can be learned. Humans are able to reflect on their own behavior, and can manage and control their behavior and can learn new behaviors or can influence others. Behavioral therapy aims to improve people's skills so they have more options to respond. By overcoming the debilitating behavior that limits choices, people are more freely to choose from possibilities that are not available before. Many studies have discussed tax compliance, factors affecting social, cultural, gender, regional and other norms, but certainly have not found out which factors can significantly and materially increase tax targets. It is a challenge for the government to find effective and efficient ways to find the main cause of taxpayer compliance in contributing to the state by paying taxes. This study will look for factors that can influence taxpayer behavior to comply. According to previous research that behavior can change and can be formed. About the method will used, will used empirical data that exist, then on though by using certain appropriate tools and then supported by the data of interviews or the spread of questinoner. This study will attempt to explore and explore the taxpayer's customary behavior factor to abide by taxes.
\end{abstract}

Keywords: behavior, tax compliance, taxpayers, tax target, Challenge

\section{Introduction}

Behavior traditional Theory begin 1950's and early 1960's in US, South Africa, and English as radical against perspective phsicoanalisis, Prior much research about tax compliance from social norms, managerial, economic influence behavior [13].

The historical development of behavioral consists of three trends:

1. 1960's Albert Bandura, social learning theory, combine classic with conditioning observation. Focus behavior therapy.

2. 1980s which is characterized by the search for new concepts and methods that go beyond traditional learning theories, end of 1990-s Assosiation Behavior and Cognitive Therapy stands.

3. Early 2000's, behavioral traditions emerge, enlarge the scope of research and practice. Recent developments include dialectical behavior therapy, stress-based awarenessbased awareness, cognitive-based awareness awareness, and acceptance and commitment therapy. 
The following about Role of Social Norms constructs [12]

\begin{tabular}{|l|l|l|l|l|}
\hline & Descriptive norms & Injunctive norms & Subjective norms & Personal norms \\
\hline Description & $\begin{array}{l}\text { What one perceives that } \\
\text { other people do in a given } \\
\text { situation. Watching others } \\
\text { provides information about } \\
\text { what is "normal' in a novel or } \\
\text { ambiguous situation }\end{array}$ & $\begin{array}{l}\text { The perception of what most } \\
\text { people think others should } \\
\text { do in a given situation. They } \\
\text { specify what should be done } \\
\text { and are the moral rules of } \\
\text { the group }\end{array}$ & $\begin{array}{l}\text { A person's perception about what } \\
\text { those who are important to him } \\
\text { think he should do in a given } \\
\text { situation. They are one's } \\
\text { perceptions of the injunctive norms } \\
\text { held by } \\
\text { the people whose opinions } \\
\text { matter most }\end{array}$ & $\begin{array}{l}\text { Self-based standards or } \\
\text { expectations for behavior } \\
\text { (i.e., what an individual } \\
\text { believes he/she should do) } \\
\text { in a given situation. These } \\
\text { standards arise from } \\
\text { internalized values }\end{array}$ \\
\hline $\begin{array}{l}\text { Social goal } \\
\text { being } \\
\text { achieved by } \\
\text { conforming } \\
\text { to norm }\end{array}$ & $\begin{array}{l}\text { Effective action - the desire } \\
\text { to be accurate in one's } \\
\text { choices and behaviors }\end{array}$ & $\begin{array}{l}\text { Building and maintaining } \\
\text { social relationships }\end{array}$ & $\begin{array}{l}\text { Building and maintaining } \\
\text { social relationships }\end{array}$ & Managing self-concept \\
\hline $\begin{array}{l}\text { When will } \\
\text { they matter? }\end{array}$ & $\begin{array}{l}\text { Most likely to use evidence } \\
\text { of others' behavior to decide } \\
\text { most effective course of } \\
\text { action when the situation is } \\
\text { novel, ambiguous, or } \\
\text { uncertain, and especially } \\
\text { when the source of reference } \\
\text { is similar to us }\end{array}$ & $\begin{array}{l}\text { They motivate behavior by } \\
\text { promising social rewards or } \\
\text { punishments. Need not be } \\
\text { expressed in order to direct } \\
\text { behavior. These norms are } \\
\text { more influential when they } \\
\text { are made salient }\end{array}$ & $\begin{array}{l}\text { When people are motivated to } \\
\text { comply with the norms of } \\
\text { "referent" others }\end{array}$ & $\begin{array}{l}\text { Enforced through the } \\
\text { anticipation of self } \\
\text { enhancement or self - } \\
\text { deprecation ("self- } \\
\text { reinforcing") }\end{array}$ \\
\hline
\end{tabular}


The following about prior tax compliance research on social norms [13]

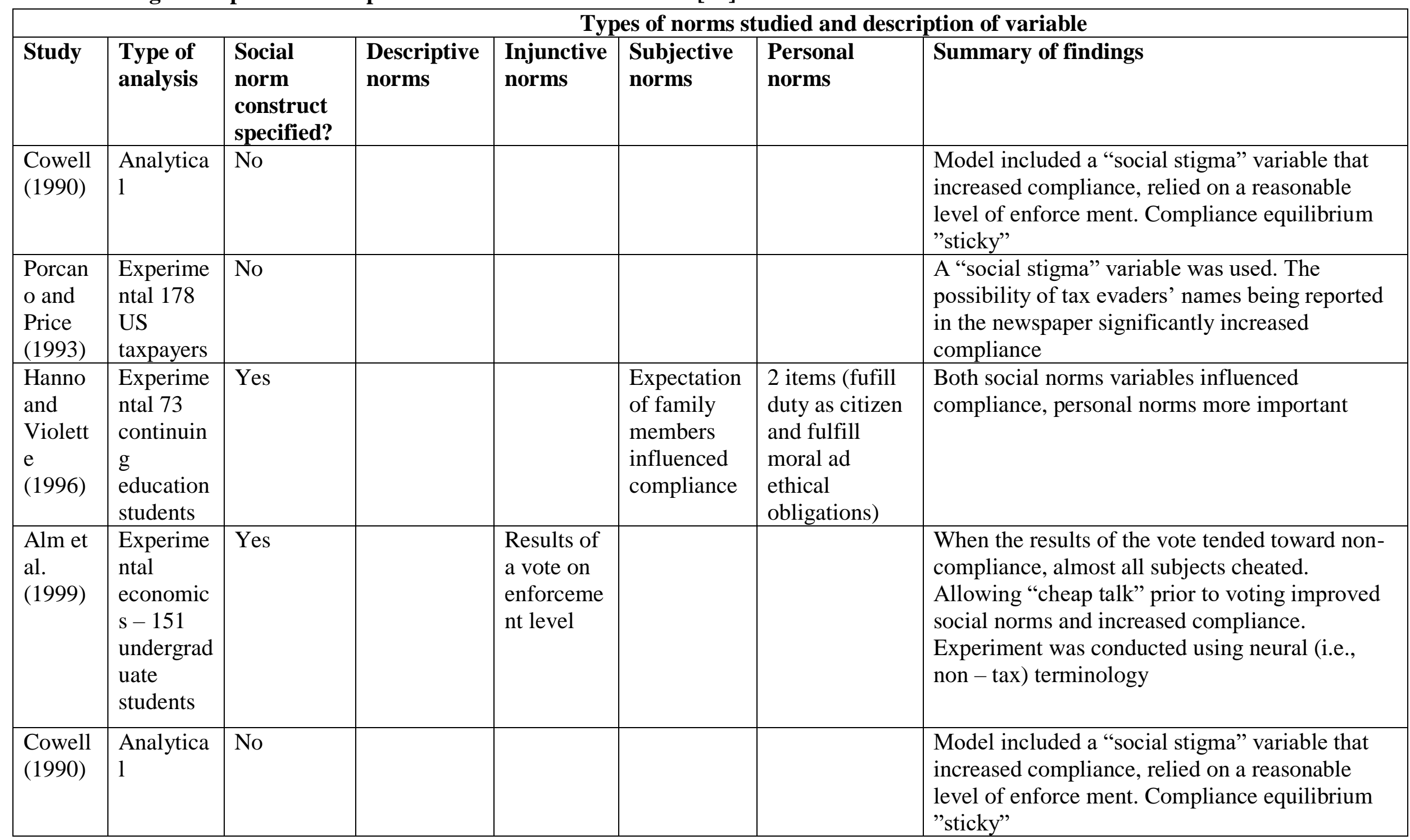




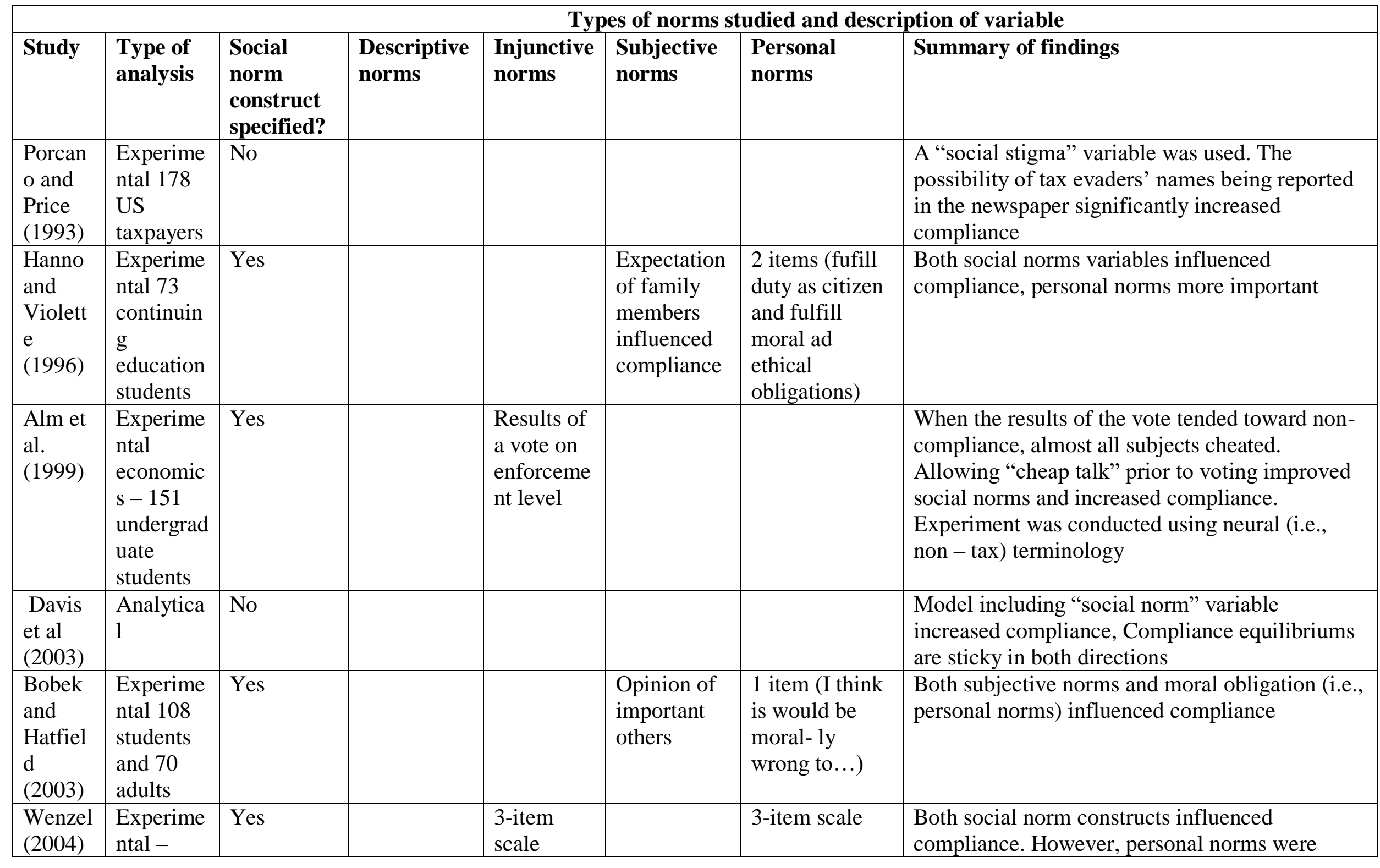




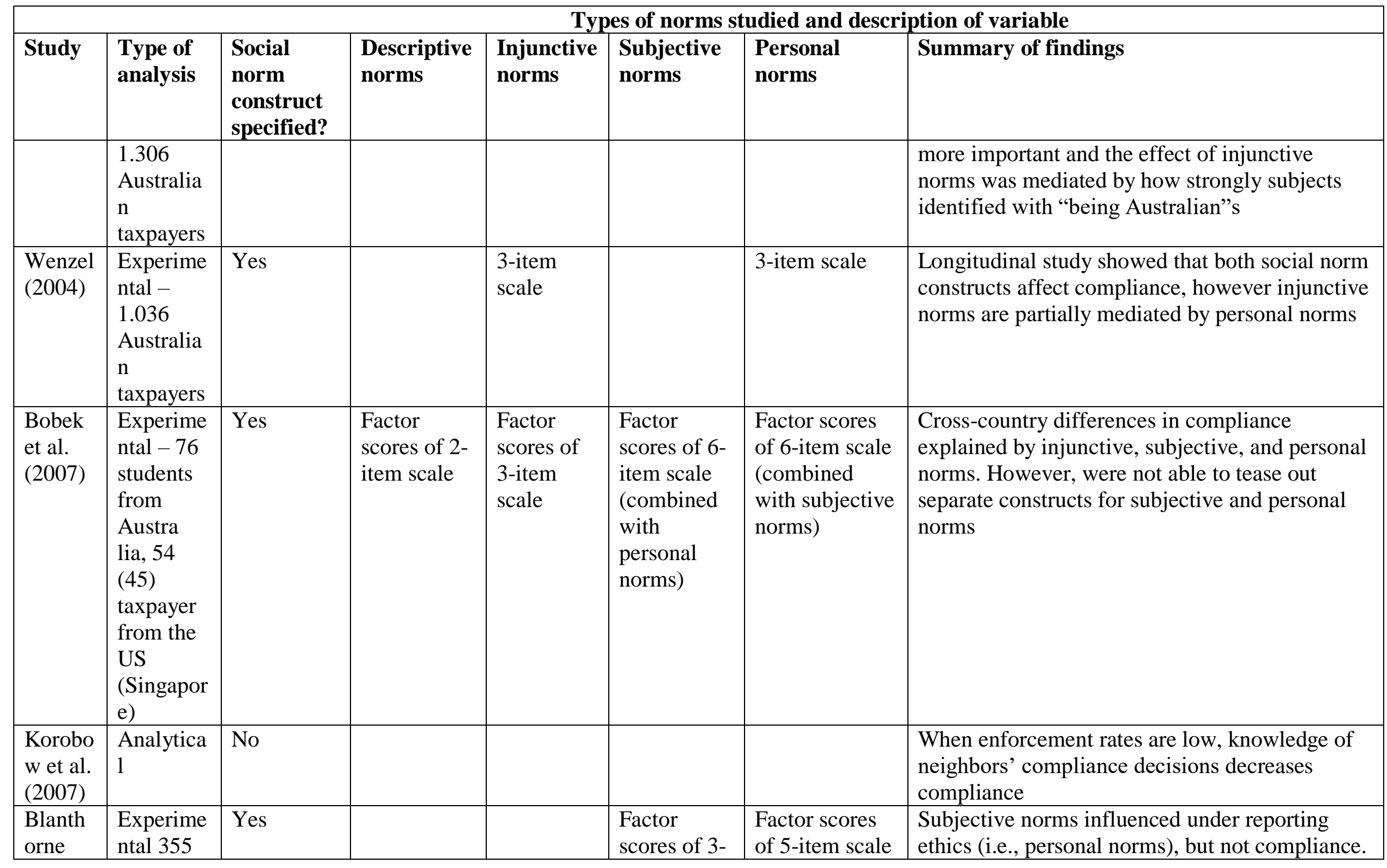




\begin{tabular}{|c|c|c|c|c|c|c|c|}
\hline \multicolumn{8}{|c|}{ Types of norms studied and description of variable } \\
\hline $\begin{array}{l}\text { and } \\
\text { Kaplan } \\
\text { (2008) }\end{array}$ & $\begin{array}{l}\text { US } \\
\text { taxpayers }\end{array}$ & & & & item scale & & Underreporting ethics affected compliance \\
\hline
\end{tabular}




\section{Literature Review}

Generally, the strong the intention is the more likely the behavior will be performed. Attitude toward this Behavior refers to the degree to which a person has positive or negative feelings of the behavior of interest. It entails a consideration of the outcomes of performing the behavior [22].

The role of behavioural and psychological aspects in compliance behaviour is currently one of the greatest areas of tax compliance research, and, although several accomplishments have been achieved, there is still countless room for development [47].

Prior tax compliance research on social norms [12], Social norms have important direct as well as indirect influences on tax compliance behavior [13], Tax compliance as a coordination game [6], Social Influence: Social Norms, Conformity, and Compliance [20], Research into economic and behavioural approaches in tax compliance [2], Misperceptions of social norms about tax compliance [68].

When faced with tax moral dilemmas, it is generally believed that ethics can serve as guidelines for taxpayers on how to act rightly and justly [34].

The development of tax decision-making models has focused on economic and behavioral factors affecting compliance. A possible explanatory factor that has been overlooked in these decision- making models is tax ethical beliefs [55]. Specifically, the research empirically tests whether an individual's ethical beliefs about tax compliance mediate withhold- ing effects (overwithheld or tax due) and tax rate effects (low or high) in tax eva-sion decisions. The results indicate that tax ethics are highly significant in tax eva-sion decisions and may be a "missing variable" in decision making models [55].

The attitude of taxpayers varies considerably. Some comply to the fullest extent required, irrespective of whether the IRS is actively auditing them or their industry. Other taxpayers essentially play the audit lottery and either do not prepare contemporaneous documentation or prepare the absolute minimum with the hope of avoiding the imposition of penalties [64].

The Theory of Planned Behavior (TPB) predicts an individual's intention to engage in a behavior at a specific time and place. It posits that individual behavior is driven by behavior intentions, where behavior intentions are a function of three determinants: an individual's attitude toward behavior, subjective norms, and perceived behavioral control [1].

Personal norms (individual ethics and morality of tax paying) on levels of tax compliance, findings for the role of social norms (ethics and morality attributed to other taxpayers) on tax compliance have been more ambiguous [69].

Reciprocity considerations are important to the tax compliance problem as they may explain the global dynamics of tax evasion, beyond individual tax evasion decisions, taxpayers may react to a disadvantageous or advantageous inequity through negative or positive reciprocal behaviors, respectively [9].

Taxpayer audits are a central feature of the voluntary compliance system in the United States federal individual income tax. Audits are thought to have a direct deterrent effect on the 
individuals actually audited. In addition, audits are believed to have an indirect deterrent effect on individuals not audited, and there is some empirical evidence that suggests that changes in audit rates affect compliance beyond the audited individuals themselves. However, empirical studies cannot measure or control for taxpayer awareness of audit risk. As a result, there is no evidence on the magnitude of the effects of audit risk awareness on taxpayer compliance; that is, the effects on compliance of the ways in which taxpayers learn about - and communicate among themselves - audit rates are not known, and cannot be addressed or discovered by empirical studies [5].

In fact, some of these standard instruments-greater penalties-may be largely ineffective in increasing tax compliance. In short, government should pursue a range opproaches in its efforts to promote compliance [3].

That tax compliance behavior can also be observed like behavior in other fields, in this case we can see and find some problems for the discussion of tax compliance, the first of their research on social norms, economics, ethics, culture, the influence of tax compliance, directly indirectly affect the compliance behavior, the question arises how research can further acquire and discover other factors and or find new social norms that are likely to affect tax compliance behavior other than those previously conducted.

The second, some cases, experiments, research, research on social norms, economics, ethics, culture etc. that exist. Which factors and behaviors significantly influence taxpayers' behavior that impact on achieving tax targets.

\section{Research Method}

According to review researchs, this study make mixed method. Most likely this is due to the fact that mixed methods research is appropriate for various research disciplines in the field of social science [23]. For example, suggest that mixed-method research has become a "third research paradigm" (40).

In tax studies, the use of mixed methods has also been supported. For example, [44] suggests that in the study of mixed methods, findings using an approach can be used to inform, validate or compensate for weaknesses using other approaches. Based on the above advantages using mixed methods in tax studies, and using pragmatism as a research lens.

\section{Conclusion}

This study will attempt to explore and explore the taxpayer's customary behavior factor to abide by taxes. That the behavior of tax compliance can also be as observable as behavior in other fields. It is a challenge for the government to continue researching how to form taxabusive behavior to achieve the expected tax target. That compliance behavior can be established based on previous research, and various methods for finding the factors that influence behavior have been used. In discovering the behavior of taxpayers to comply with taxes so that tax targets are met make the importance of continuous research so that factors significantly affecting tax compliance can continue to be found as development progresses. 
Research efforts in relation to finding and discovering which factors most influence the behavioral habits of obedience can be tried, there may be other factors that have not previously been studied.

This review can be the conclusion for hypothesis:

1. If no social norm construct specified inserted, or if one of norms whether or not, the results can be different

2. If another factor included, as economic, ethic etc, the results of behavior are different too

\section{References}

[1] Ajzen Icek, The Theory of Planned Behavior, Organizational Behavior and Human Decision Process, 50 (1991) 179-211, https://www.sciencedirect.com/science/article/pii /074959789190020T

[2] Alley, C., \& James, S., Research into economic and behavioural approaches in tax compliance. In A. Sawyer (Ed.), Taxation Issues in Twenty-First Century, Christchurch: The Centre for Commercial and Corporate Law, School of Law (2006) 3-14

[3] Alm, James., Betty R. Jackson, Michael McKee, Estimating The Determinants of Taxpayer Compliance With Experimental Data, National Tax Journal, 45(1992),107-14.

[4] Alm, James., Gary H. McClelland and William D. Schulz, Changing the Social Norm of Tax Compliance by Voting, KYKLOS, 52 (1999), 141-171

[5] Alm, James., Betty R. Jackson, Michael McKee, Audit Information Dessemination, Taxpayer Communication and Tax Compliance: An Experimental Investigation of Indirect Audit Effects, Paper presented at the 97th Annual Conference of theNational Tax Association Minneapolis, MN. (2004)

[6] Alm, James, Michael McKee, Tax compliance as a coordination game. Journal of Economic Behavior \& Organization. 54 (2004), 297-312

[7] Alm, James., Benno Torgler, Do Ethics Matter? Tax Compliance and Morality, tukane University: Tulane Economics Working Paper Series, Working Paper 1207, (2012)

[8] Andreoni, James, Brian Erard, Jonathan Feinstrein. Tax Compliance. Journal of Economic Literature, 36 (1998), 818-860

[9] Bazart, Cécile., Aurélie Bonein, Reciprocal relationships in tax compliance decisions, Journal of Economic Psychology, Elsevier, 40 (Special Issue on Behavioral Dynamics of Tax Evasion) (2014), 83-102

[10] Binaj, Ilir., An Evaluation of the Impact of Corruption, Tax Burden, and Income on the Size of the Shadow Economy, International Journal of Accounting and Taxation, 3 (2015), 15-27 
[11] Blumenthal, M., Charles Christian, Joel Slemrod, Do Normative Appeals Affect Tax Compliance? Evidence from a Controlled Experiment in Minnesota, National Tax Journal, 54 (2001), 125-138

[12] Bobek, Donna D., Robin W. Roberts, John T. Sweeney, The Social Norms of Tax Compliance: Evidence from Australia, Singapore, and the United States, Journal of Business Ethics, 74 (2007), 49-64

[13] Bobek, Donna D., Amy M. Hageman, Charles F. Kelliher, Analyzing the Role of Social Norms in Tax Compliance Behavior, Jurnal Bussiness Ethics, 115 (2013), 451-468

[14] Bobek, Donna D., Richard C.Hatfield, An Investigation of the Theory of Planned Behavior and the Role of Moral Obligation in Tax Compliance, Behavoiral Research In Accounting, USA, 15, (2003)

[15] Braun, V., \& Clarke, V., Using thematic analysis in psychology. Qualitative Research in Psychology, 3 (2006), 77-101.

[16] Cadsby, C. Bram, Elizabeth Maynes, Viswanath Umashanker Trivedi. Tax Compliance and Obedience to Authority at Home and in the Lab: A New Experimental Approach

[17] Chau, Gerald., Patrick Leung, A critical review of Fischer tax compliance model: A research synthesis, School of Accounting and Finance, the Hong Kong Polytechnic University, Hung Hom, Kowloon, Hong Kong. Journal of Accounting and Taxation, 1 (2009), 034-040

[18] Chung, Janne, Viswanath Umashanker Trivedi, the Effect of Friendly Persuasion and Gender on Tax Compliance Behavior, Journal of Business Ethics, 47 (2003), 133-145

[19] Cialdini, Robert B., Carl A. Kallgren, Raymond R. Reno, A Focus Theory of Normative Conduct: A Theoretical Refinement and Reevaluation of The Role of Norms In Human Behavior, Academic Press, Inc.,Advance in Experimental Social Psychology, 24 (1991)

[20] Cialdini, Robert B., Melanie R. Trost, Social Influence: Social Norms, Conformity, and Compliance, Chapter 21, (1998), 150-192

[21] Cialdini, Robert B. and Noah J. Goldstein, SOCIAL INFLUENCE: Compliance and Conformity. Annu. Rev. Psychol, 55 (2003), 591-621

[22] Conner, M., \& Armitage, C. J. Extending the theory of planned behavior: A review and avenues for future research. Journal of Applied Social Psychology, 28(1998), 14291464

[23] Creswell, J. W., \& Plano Clark, V. L., Designing and conducting mixed methods research. Thousand Oaks, California: Sage Publications Inc, (2011)

[24] Cummings, Ronald G., Jorge Martinez-Vazquez, Michael McKee, Benno Torgler. Tax Morale Affects Tax Compliance: Evidence from Surveys and an Artefactual Field Experiment, Journal of Economic Behavior \& Organization, (2008)

[25] Daniel Ho, Brossa Wong,) "Issues on compliance and ethics in taxation: what do we know?", Journal of Financial Crime, 15 (2008), 369-382 
[26] Devos, Ken., The impact of tax professionals upon the compliance behavior of Australian individual taxpayers, Revenue Law Journal, 22 (2012)

[27] Dijke, Marius van, Peter Verboon. Trust in authorities as a boundary condition to procedural fairness effects on tax compliance, Journal of Economic Psychology, 31 (2010), 80-91

[28] Gabriela, Stefura, The Role of Opportunity, Taxpayers Perception and Demographic Difference in Tax Compliance Analysis, Alexandru Ioan Cuza University, gabi.stefura@gmail.com.

[29] Gabriela, Stefura, The Role Played by Economic and Noneconomic Variables in The Analysis of Tax Compliance ,Revie of Economic and Business Studies, 4 (2011), 105120

[30] Gangl, Katharina, Benno Torgler, Erich Kirchler, Eva Hofmann. Effects of supervision on tax compliance: Evidence from a field experiment in Austria, Center for Research in Economics, Management and the Arts, Working Paper No. 2013-15.

[31] Gayer, Christian., Gilles Mourre, Property taxation and enhanced tax administration in challenging times, European Economy: Economic Papers 463, (2012).

[32] Gogsadze, Teimuraz., Tax Compliance: A Behavioral Economics Approach. Thesis submitted for the degree of Doctor of Philosophy at the University of Leicester, 2016

[33] Hasseldine, John., Peggy Hite, Simon James, Marika Toumi, Persuasive Communications: Tax Compliance Enforcement Strategies for Sole Proprietors, Contemporary Accounting Research, 24 (2007), 171-194

[34] Ho, Daniel, Brossa Wong, A Study of Hong Kong Tax Compliance Ethics, Department of Accountancy \& Law, School of Business, Hong Kong Baptist University Kowloon Tong, Hong Kong, International Business Research, 2 (2009)

[35] Hofstede, G., Culture's consequences: international differences in work related values. Beverly Hills: Sage Publication, 1980

[36] Iyer, G.S., Philip M. J. Reckers, Debra L. Sanders, Increasing Tax Compliance In Washington State: A Field Experiment, National Tax Journal, 63 (2010), 7-32

[37] James, Simon., Alison Edwards. An Annotated Bibliography of Tax Compliance and Tax Compliance Costs, University of Exeter Business School, Economic and Social Research Council funding is gratefully acknowledged (award number RES-000-231595 'Optimum Tax Compliance Costs and Tax Simplification'), 2010

[38] James, Simon, Alley C., Tax Compliance, Self-Assessment and Tax Administration, Journal of Finance and Management in Public Services, 2 (1999), 1-27

[39] Jackson, B. R., \& Milliron, V. C., Tax compliance research: findings, problems and prospects. Journal of Accounting Literature, 5 (1986), 125-161

[40] Johnson, R. B., \& Onwuegbuzie, A. J., Mixed methods research: A research paradigm whose time has come. Educational Researcher, 33 (2004), 14-26 
[41] Kaplan, S. E., K. J. Newberry and P. M. J. Reckers, 'The Effect of Moral Reasoning and Educational Communication on Tax Evasion Intentions', the Journal of the American Taxation Association, 19 (1997) 38-54

[42] Kallgren, Carl A., Raymond R. Reno, Robert B. Cialdin. A Focus Theory of Normative Conduct: When Norms Do and Do Not Affect Behavior, the Society for Personality and Social Psychology, Inc, PSPB, 26 (2000), 1002-1012

[43] Kastlunger,B., Stefan G. Dressler, Erich Kirchler, Luigi Mittone, Martin Voracek, Sex differences in tax compliance: Differentiating between demographicsex, gender-role orientation, and prenatal masculinization (2D:4D), Journal of Economic Psychology, 31 (2010), 542-555

[44] Kirchler, Erich, Ingrid Wahl. Tax Compliance Inventory: TAX-I Voluntary tax compliance, enforced tax compliance, tax avoidance, and tax evasion, J Econ Psychol, Vol. 31 (2010), 331-346

[45] Leder, Susanne., Lucia Mannetti, Erik Hölzl, Erich Kirchler, Regulatory fit effects on perceived fiscal exchange and tax compliance, J Socio Econ, 39 (2010), 271-77

[46] Lincoln, Y. S., \& Guba, E. G., Naturalistic Inquiry. Beverly Hills, California: Sage Publications Inc., 1985

[47] Loureiro, Joana Manuela Sá Paiva, Behavioural Economics and Tax Compliance: The role of identifiability, geographical distance and social norms on tax compliance: an experimental study, 2014

[48] Luttmer, Erzo F. P., Monica Singhal, Tax Moral.e, Journal of Economic Perspectives, 28 (2014), 149-168

[49] Mahangila, Managers or Corporates?: Curbing Non-compliance through Corporate Income Tax Penalty, Department of Accounting, University of Dar es Salaam Business School Tanzania: Business Management Review. (2016), 82-104

[50] Marandu, Edward E., Christian J. Mbekomize, Alexander N. Ifezue, Determinants of Tax Compliance: A Review of Factors and Conceptualizations, Canadian Center of Science and Education: International Journal of Economics and Finance; 7 (2015)

[51] Murray, M.N., Sales Tax Compliance and Audit Selection, National Tax Journal 48 (1995), 515-530

[52] Onu, Diana, Lynne Oats. Social Norms and Tax Compliance. Tax Administration Research Center, Discussion Paper: 006-14.

[53] Onu, Diana, Lynne Oats, The role of social norms in tax compliance: theoretical overview and practical implications, Journal of Tax Administration Vol.1:1

[54] Peñas, Ignacio Lago, Santiago Lago-Peñas. The Determinants of Tax Morale in Comparative Perspective: Evidence from A Multilevel Analysis the Determinants of Tax Morale in Comparative Perspective: Evidence from A Multilevel Analysis, P. T. N.02/08. 
[55] Reckers, P. M. J., Sanders, D. L., \& Roark, S. J., The Influence of Ethical Attitudes on Taxpayer Compliance, National Tax Journal, 47(1994), 825-36

[56] Saad, Natrah, Tax Knowledge, Tax Complexity and Tax Compliance: Taxpayers'View, Procedia - Social and Behavioral Sciences, 109 (2014), 1069 - 1075

[57] Sanders, D.L., Philip M J Reckers, Govind S Iyer, Influence of Accountability and Penalty Awareness on Tax Compliance, The Journal of the American Taxation Association, 30 (2008), 1-20

[58] Schwartz, Shalom H., Normative Explanations of Helping Behavior: A Critique, proposal, and Empirical Test, University of Wisconsin: Journal of experimental Social Psychology, 9 (1973), 349-364

[59] Stefura, Gabriela, A New Perspective on Individual Tax Compliance: The Role of The Income Source, Audit Probability and The Chance of Being Detected. The USV Annals of Economics and Public Administration, 12 (2012)

[60] Suhaila Abdul Hamid, Tax Compliance Behaviour of Tax Agents: A Comparative Study of Malaysia and New Zealand, A thesis submitted in fulfilment of the requirements for the Degree of Doctor of Philosophy in Taxation in the University of Canterbury, 2013

[61] Snyder M., Self-monitoring of expressive behavior, Journal Personal. Soc. Psychol, 1974

[62] Torgler, Benno, Tax Morale, Rule-Governed Behaviour and Trust, Constitutional Political Economy, 14 (2003), 119 - 140

[63] Traxler, Christian, Social norms and conditional cooperative taxpayers. European Journal of Political Economy. 26 (2010), 89-103

[64] Trivedi, V.U., Mohamed Shehata, Stuart Mestelman, Attitudes, Incentives, and Tax Compliance, Canadian Tax Journal / Revue Fiscale Canadienne, 53 (2005)

[65] Twum, E.B., Gift Tax Compliance in Ghana, an Empirical Study, Journal of Finance and Accounting, 2 (2014), 1-7

[66] U.S. Department of the Treasury, Update on Reducing the Federal Tax Gap and Improving Voluntary Compliance, 2009

[67] Vossler, Christian, Michael McKee, Michael Jones. Some Effects of Tax Information Services Reliability and Availability on Tax Reporting Behavior

[68] Wenzel, M., Misperceptions of social norms about tax compliance (2): A field experiment, Centre for Tax System Integrity, Research School of Social Sciences, Australian National University: Working Paper no. 8., 2001

[69] Wenzel, M., An analysis of norm processes in tax compliance. Journal of Economic Psychology, 25 (2004), 213

[70] Wenzel, M., Motivation or rationalization? Causal relations between ethics, norms, and tax compliance. Journal of Economic Psychology, 26 (2005), 491-500 
[71] Nan Zhang, Giulia Andrighetto, Stefania Ottone, Ferruccio Ponzano, Sven Steinmo, "Willing to Pay?" Tax Compliance in Britain and Italy: an Experimental Analysis, PLOS Journals, 2007

[72] Yong, S. S. E., Tax compliance and small and medium enterprise operators: An intracultural study in New Zealand. Doctor of Philosophy, Auckland University of Technology, Auckland, 2011 